Article

\title{
Olivine-Spinel Diffusivity Patterns in Chromitites and Dunites from the Finero Phlogopite-Peridotite (Ivrea-Verbano Zone, Southern Alps): Implications for the Thermal History of the Massif
}

\author{
Micol Bussolesi ${ }^{1}$ (D) Giovanni Grieco ${ }^{1, *(D)}$ and Evangelos Tzamos ${ }^{2,3}$ (D) \\ 1 Department of Earth Sciences, Università degli Studi di Milano, via Botticelli 23, 20133 Milan, Italy; \\ micol.bussolesi@unimi.it \\ 2 Department of Geology and Geoenvironment, National and Kapodistrian University of \\ Athens (Zografou Campus), 15784 Athens, Greece; etzamos@geol.uoa.gr \\ 3 Ecoresources PC, Avdela str. 5, Kalamaria, 55131 Thessaloniki, Greece \\ * Correspondence: giovanni.grieco@unimi.it; Tel.: +39-02-5031-5629
}

Received: 20 December 2018; Accepted: 24 January 2019; Published: 27 January 2019

\begin{abstract}
The study of $\mathrm{Mg}-\mathrm{Fe}^{2+}$ subsolidus exchange between olivine and spinel is a powerful tool to unravel the thermal history of ultramafic rocks. We have implemented such a study using olivine-spinel diffusivity patterns in fresh mineralogical samples from the Finero mafic-ultramafic Complex in the Ivrea-Verbano zone of Northern Italy. Our analytical suite includes chromitites and dunites of the Phlogopite-Peridotite Unit from the core of the Complex. Primary and re-equilibrated olivine and spinel compositions were derived from diffusivity curves calculated by fitting data via an exponential function. Resulting $\mathrm{XMg}\left(\mathrm{Mg} /\left(\mathrm{Mg}+\mathrm{Fe}^{2+}\right)\right.$ values were then used for geothermometry. Samples are found to demonstrate a maximum temperature of $849^{\circ} \mathrm{C}$ and a minimum temperature of $656^{\circ} \mathrm{C}$; these temperatures coincide with the limits of elemental exchange in this mineralogic system. We were unable to identify primary olivine/spinel compositions related to the original formation of the dunite-chromitite suite during Early Permian metasomatic activity. Temperature of $849{ }^{\circ} \mathrm{C}$ is ascribed to the Late Triassic re-heating event dated at $208 \pm 2 \mathrm{Ma}$. Continuous cooling followed this event at rates of $10^{-4}$ and $10^{-2}{ }^{\circ} \mathrm{C} / \mathrm{yr}$ until cessation of elemental exchange activity at $\sim 656^{\circ} \mathrm{C}$. A rapid cooling rate is associated with the uplift and subsequent decrease of geothermal gradient during the early stages of the opening of the Piemont ocean basin.
\end{abstract}

Keywords: Finero complex; chromitite; olivine-spinel equilibrium; geothermometry; diffusivity patterns; cooling rates

\section{Introduction}

Chromian spinel shows a wide compositional range, sensitive to changes in thermal conditions [1]. Chemical reactions between chromite and surrounding silicates involve a strongly temperature-dependent partitioning of $\mathrm{Mg}$ and $\mathrm{Fe}^{2+}$ that facilitates the use as a geothermometer [1-4]. Olivine-spinel subsolidus exchange covers a wide range of temperatures, from high- $\mathrm{T}$ conditions down to at least $650{ }^{\circ} \mathrm{C}$, that is, at the cessation of elemental exchange between the two minerals [3,5-7].

While $\mathrm{Mg}-\mathrm{Fe}^{2+}$ partitioning between olivine and spinel has been extensively studied within peridotites $[1,2,4,8-10]$, recent studies are beginning to highlight its importance within chromitites [11]. Chromite modal content plays a crucial role in chromite re-equilibration: cores of $\mathrm{Cr}$-spinel retain their primary composition under certain conditions. These compositions demonstrate heterogeneity between chromite and olivine crystals that result in a regular trend of the $\mathrm{XMg}\left[\mathrm{Mg} /\left(\mathrm{Mg}+\mathrm{Fe}^{2+}\right)\right]$ 
within mineral grains, from rim to core, known as diffusivity pattern (or diffusivity curve) [9]. It is possible to exploit $\mathrm{Mg}-\mathrm{Fe}^{2+}$ diffusivity curves of olivine and chromite to infer not only re-equilibration conditions, but also initial high-T conditions.

Our case study examines the temperature and re-equilibration conditions deduced from chromitites, chromitite-bearing dunites and chromitite-free dunites of the Finero complex, the largest peridotite massif of the Ivrea-Verbano Zone, Northern Italy. At the core of this complex, within the Phlogopite-Peridotite unit, several non-altered chromitite pods provide an effective opportunity to use olivine-spinel diffusivity patterns as tools for the reconstruction of the thermal history of chromitite-bearing massifs.

\section{Geological Setting}

The Ivrea-Verbano zone is a geodynamic domain of the Southern Alps in Northern Italy. It is a complete section extending through deep continental crust [12] and consisting of amphibolite-to-granulite facies paragneiss intruded by huge volumes of mafic to intermediate plutonic rocks [13]. Three peridotite bodies are exposed at the base of the Mafic Complex, along the Insubric Line, a major tectonic lineament separating South-Alpine and Austro-Alpine domains. From South to North, these are Baldissero, Balmuccia and Finero massifs.

The Finero peridotite is part of the Finero Mafic-Ultramafic Complex (Figure 1). This comprises, from external contact to interior, four main units: External Gabbro, Amphibole Peridotite, Layered Internal Zone and Phlogopite-Peridotite [14]. The External Gabbro consists of garnet-amphibole bearing gabbros with rare pyroxenitic and anorthositic layers. The Amphibole Peridotite comprises dunites, wherlites and lherzolites enriched in pargasitic amphibole. The Layered Internal Zone consists of cm-thick lithologic layers of amphibole-peridotite, amphibole-websterite, garnet-amphibole gabbros and anorthosite. The Phlogopite-Peridotite unit, mainly harzburgite, shows some peculiar features that differentiate it from the other peridotite bodies of the area. The first one is the presence of chromitite-bearing metasomatic dunites within harzburgites, cut by clinopyroxenite dykes. The second one is a pervasive re-fertilization of the primary mantle assemblage witnessed by phlogopite and pargasitic-to-edenitic amphibole [14-18].

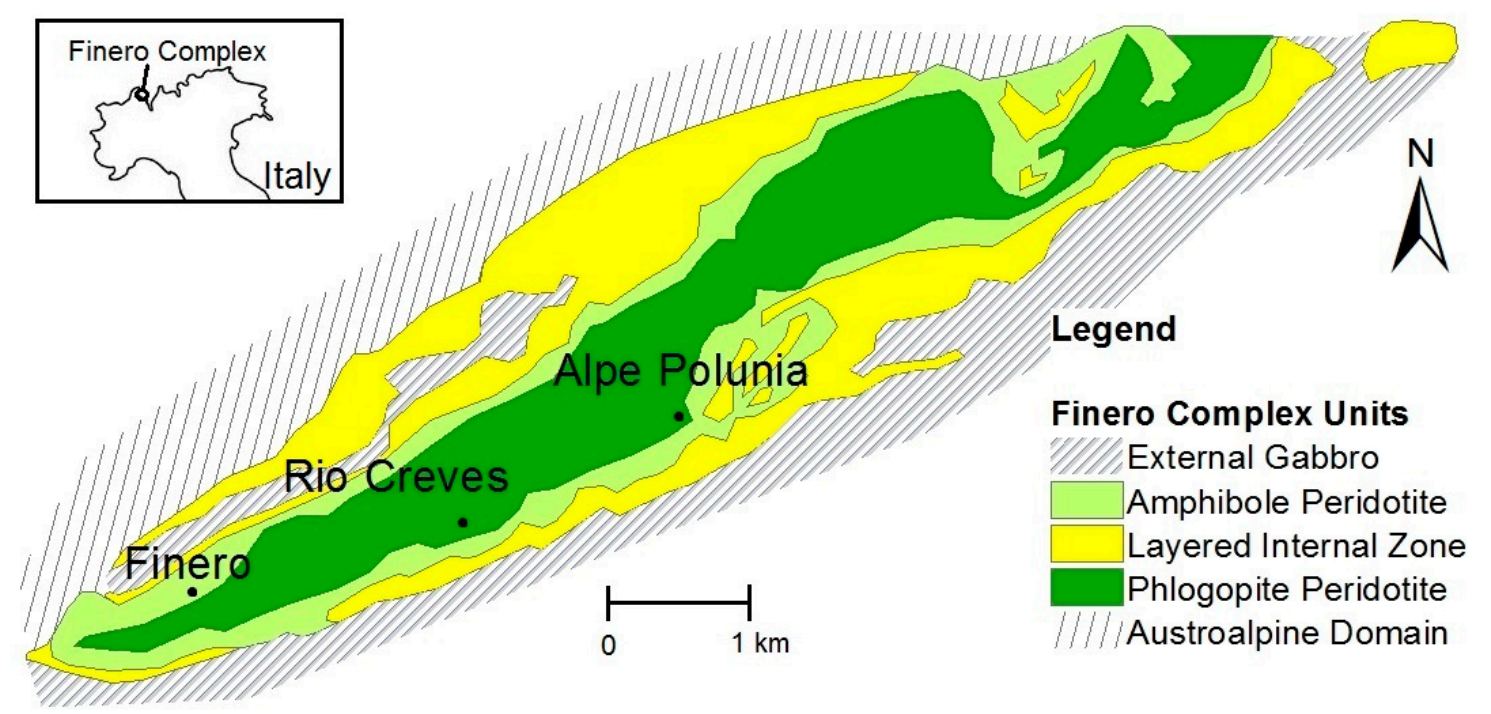

Figure 1. Simplified geological map of the Finero Complex, Ivrea-Verbano Zone, Northern Italy.

\section{Analytical Methods}

We have analyzed chromitite samples from two localities (Polunia and Rio Creves) and a dunite sample from the Rio Creves locality (Figure 1). In order to study the $\mathrm{Mg}-\mathrm{Fe}^{2+}$ exchange between olivine and spinel, seven small $(\sim 100 \times 100 \mu \mathrm{m})$ regions within these samples were chosen for a 
detailed investigation involving a high density of microprobe analyses arranged in grids and traverses: an increasing number of analyses was conducted near grain boundaries. The average number of points analyzed within specific areas of a sample ranges between 40 and 100 (see Supplementary Materials for the analyses).

A JEOL 8200 electron microprobe (JEOL Ltd., Akishima, Japan) equipped with a wavelength dispersive system (WDS) at the Earth Sciences Department of the University of Milan was used for analyses. The microprobe system operated using an accelerating voltage of $15 \mathrm{kV}$, a sample current on brass of $15 \mathrm{nA}$, a counting time of $20 \mathrm{~s}$ on the peaks and $10 \mathrm{~s}$ on the background. Beam diameter is $1 \mu \mathrm{m}$. A series of natural minerals was used as standards: wollastonite for $\mathrm{Si}$, forsterite for $\mathrm{Mg}$, ilmenite for $\mathrm{Ti}$, fayalite for $\mathrm{Fe}$, anorthite for $\mathrm{Al}$ and $\mathrm{Ca}$, metallic $\mathrm{Cr}$ for $\mathrm{Cr}$, niccolite for $\mathrm{Ni}$, rhodonite for $\mathrm{Mn}$ and $\mathrm{Zn}$, and metallic $\mathrm{V}$ for that element. Detection limit is approximately $330 \mathrm{ppm}$ for $\mathrm{Ti}$ (6\% standard deviation), $460 \mathrm{ppm}$ for Mn (6\% standard deviation), $160 \mathrm{ppm}$ for Mg ( $2 \%$ standard deviation), $180 \mathrm{ppm}$ for $\mathrm{Si}$ ( $6 \%$ standard deviation), $320 \mathrm{ppm}$ for V (12\% standard deviation), $370 \mathrm{ppm}$ for $\mathrm{Fe}$ ( $8 \%$ standard deviation), $140 \mathrm{ppm}$ for $\mathrm{Ca}$ ( $15 \%$ standard deviation), $135 \mathrm{ppm}$ for $\mathrm{Al}$ ( $4 \%$ standard deviation), $370 \mathrm{ppm}$ for $\mathrm{Cr}$ (10\% standard deviation), $390 \mathrm{ppm}$ for $\mathrm{Ni}$ ( $9 \%$ standard deviation) and $800 \mathrm{ppm}$ for $\mathrm{Zn}$ (9\% standard deviation). Trace element detection limits are based on multiple analyses of the standard material, carried out at the beginning of each microprobe session. $\mathrm{Fe}^{3+}$ was recalculated from microprobe analyses assuming perfect stoichiometry of the minerals, based on 8-oxygen formula.

Diffusivity profile modeling utilized OriginLab software (version OriginPro 8, OriginLab Corporation, Northampton, MA, USA). Temperature recalculations followed the methodology of Ballhaus et al. [4] and Fabriès [3] calibrations (the latter was used for the cooling rate evaluation).

\section{Texture and Mineral Chemistry}

We have analyzed chromitite occurrences in dunite bodies within the Phlogopite-Peridotite at Rio Creves and Alpe Polunia. The chromitite bodies occur as irregular pods, schlieren, lenses and discontinuous layers tens of meters long and up to half a meter thick [18].

Our samples include chromitites (up to $80 \%$ chromite modal content), their host dunites (CHD, chromitite-hosting dunites) and chromitite-free dunites (CFD, dunites not spatially correlated to chromitite lenses). The contact between chromitites and their host dunite is always sharp, characterized by a transition from massive chromitite (70-80\% modal chromite) to dunite with only dispersed spinel.

Chromites in chromitite bodies are mainly polygonal to irregular, sometimes rounded, with grain size ranging between 0.5 and $1.5 \mathrm{~mm}$ in Polunia deposits and millimetric crystals in Rio Creves deposits. Most chromitites consist of coarse-grained chromite with interstitial silicate gangue (Figure 2a). In some cases, $\mathrm{Cr}$-spinel is enclosed within olivine structural planes (Figure $2 b$ ), as firstly described by Zaccarini et al. [19]. Disseminated Cr-spinels within dunite consist of euhedral crystals of grain size less than $0.5 \mathrm{~mm}$ (Figure 2c) dispersed in a silicate matrix.

Olivine is the major silicate constituent, and is present in polygonal to irregular crystals in dunites (Figure 2d,e) and as an interstitial anhedral phase within massive chromitites (Figure 2a). Other minor constituents of the silicate matrix are orthopyroxenes (Figure 2f), rare clinopyroxene and pargasitic amphiboles. We have chosen to analyze non-serpentine bearing samples: serpentinization is limited to some major fractures cutting the occurrences.

For our study, we have analyzed regions within samples that include only olivine and spinel: these are conducive to high-density spaced analyses that we then utilized for calculation of re-equilibration conditions between the two phases without any interference induced by other mineral exchanges (e.g., pyroxene exchange with olivine and/or chromite). 


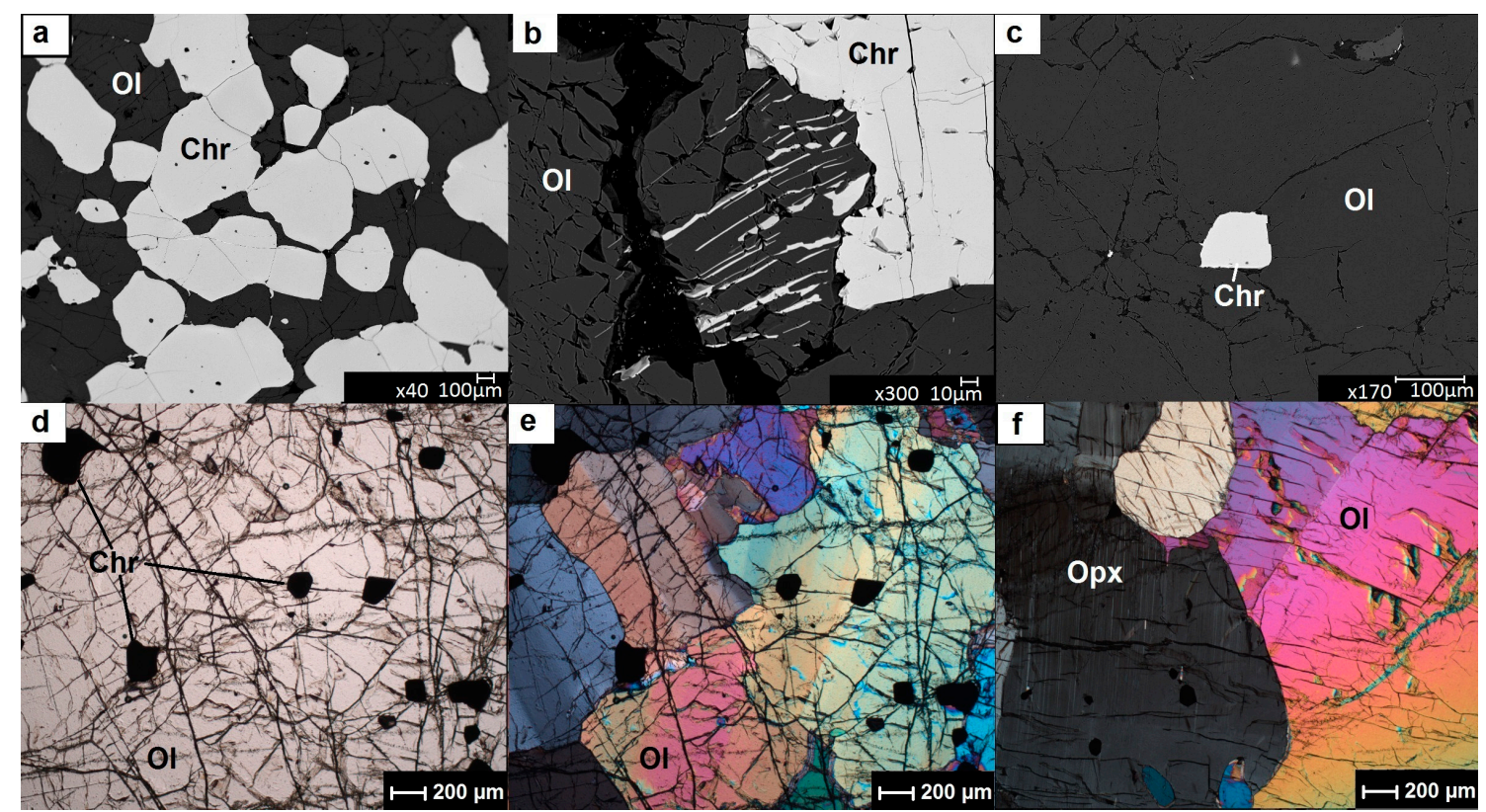

Figure 2. Chromitites and dunites from Rio Creves and Polunia. (a) BSE (Back Scattered Electrons) image of a chromitite (Polunia); (b) BSE image of chromite growth within an olivine crystal (Rio Creves); (c) BSE image of a disseminated chromite crystal in dunite (Rio Creves); (d) disseminated spinels within olivine crystals, transmitted light $(1 \mathrm{~N})$; (e) disseminated spinels (black) within olivine crystals, transmitted light $(2 \mathrm{~N})$; (f) pyroxene and olivine crystals, transmitted light $(2 \mathrm{~N})$. Mineral abbreviations are according to Whitney et al. [20].

\subsection{Chromite Mineral Chemistry}

Chromite average composition (Table 1) comprises analyses of the cores in order to avoid any effect from zonation of the mineral. Mineral chemistry of $\mathrm{Cr}$-spinel depends on the host rock: chromitite, chromitite-hosting dunite, and chromitite-free dunite.

Chromites within massive chromitites have the highest $\mathrm{MgO}$ content, ranging between 10.74 and $11.74 \mathrm{wt} \%$, and the lowest $\mathrm{FeO}$ content (16.95-18.61 wt \%). $\mathrm{Fe}_{2} \mathrm{O}_{3}$ content is between 3.40 and $6.28 \mathrm{wt} \%$. $\mathrm{Cr}_{2} \mathrm{O}_{3}$ content ranges between 50.06 and $53.92 \mathrm{wt} \%$, and $\mathrm{Al}_{2} \mathrm{O}_{3}$ content between 13.49 and $16.34 \mathrm{wt} \%$.

Chromites in CHD are characterized by a slightly lower $\mathrm{Cr}_{2} \mathrm{O}_{3}$ content $(48.60-51.32 \mathrm{wt} \%$, with an average of $50.25 \mathrm{wt} \%$ ), lower $\mathrm{MgO}$ (between 6.89 and $9.56 \mathrm{wt} \%$ ) and higher $\mathrm{FeO}(20.34-24.34 \mathrm{wt} \%$ ). $\mathrm{Al}_{2} \mathrm{O}_{3}$ content is comparable to the one in the chromite mineralization, with a variation between 13.00 and $16.42 \mathrm{wt} \%$, and $\mathrm{Fe}_{2} \mathrm{O}_{3}$ content is between 4.42 and $8.04 \mathrm{wt} \%$.

Within CFD, chromite shows lower MgO (4.41-4.68 wt \%) and higher FeO (24.97-25.42 wt \%) content. $\mathrm{Al}_{2} \mathrm{O}_{3}$ and $\mathrm{Fe}_{2} \mathrm{O}_{3}$ contents range respectively between 5.78-5.98, and 6.64-7.57 wt \%, and $\mathrm{Cr}_{2} \mathrm{O}_{3}$ concentrations are high, ranging between 56.03 and $56.83 \mathrm{wt} \%$.

Differences in major elements extend to trace element chemistry within these three Cr-spinel host groups.

Within chromitites and CHD spinels have high Ti (between 2617 and 4967 ppm, with an average of $3726 \mathrm{ppm}), \mathrm{Zn}$ (400-3173 ppm, with an average of $1645 \mathrm{ppm}$ ) and Mn (339-2820, with an average of $1492 \mathrm{ppm})$ contents, and low $\mathrm{Ni}$ (67-1560, with an average of $706 \mathrm{ppm})$ and $\mathrm{V}$ (0-779 ppm, average of $439 \mathrm{ppm})$.

Trace elements in CFD spinels show significant differences from those of chromitites and CHD in Ti concentration (294-883 ppm, with an average of $492 \mathrm{ppm}$ ), Ni (95-852, with an average of $389 \mathrm{ppm}$ ) and $\mathrm{Zn}$ (3343-5863 ppm, with an average of $4307 \mathrm{ppm}$ ), while Mn and V concentrations are, respectively, 2786-3739 (average value of $3029 \mathrm{ppm}$ ) and 30-470 ppm (average value of $246 \mathrm{ppm}$ ). 
Table 1. Major and trace elements average composition and standard deviation of chromite cores from Rio Creves and Alpe Polunia, for the three host rocks: chromitite, $\mathrm{CHD}$ and $\mathrm{CFD}$. $\mathrm{XCr}[=\mathrm{Cr} /(\mathrm{Cr}+\mathrm{Al})]$. $\mathrm{XMg}\left[=\left(\mathrm{Mg} /\left(\mathrm{Mg}+\mathrm{Fe}^{2+}\right)\right]\right.$.

\begin{tabular}{|c|c|c|c|c|c|c|c|c|c|c|}
\hline \multicolumn{11}{|c|}{ Chromite Core Analyses } \\
\hline \multirow{3}{*}{$\begin{array}{l}\text { Sample } \\
\text { Elem }\end{array}$} & \multicolumn{4}{|c|}{ Chromitite } & \multicolumn{4}{|c|}{ CHD } & \multirow{2}{*}{\multicolumn{2}{|c|}{$\begin{array}{c}\text { CFD } \\
\text { DUN-FIN }\end{array}$}} \\
\hline & \multicolumn{2}{|c|}{ FIN01A } & \multicolumn{2}{|c|}{ PO4A } & \multicolumn{2}{|c|}{ FIN02B } & \multicolumn{2}{|c|}{ PO4A } & & \\
\hline & Avg. & St. Dev. & Avg. & St. Dev. & Avg. & St. Dev. & Avg. & St. Dev. & Avg. & St. Dev. \\
\hline $\mathrm{TiO}_{2}$ & 0.618 & 0.055 & 0.577 & 0.044 & 0.673 & 0.095 & 0.561 & 0.020 & 0.088 & 0.035 \\
\hline $\mathrm{Al}_{2} \mathrm{O}_{3}$ & 14.018 & 0.434 & 15.012 & 0.376 & 13.472 & 0.278 & 15.370 & 0.731 & 5.888 & 0.066 \\
\hline $\mathrm{Cr}_{2} \mathrm{O}_{3}$ & 51.321 & 0.580 & 51.888 & 0.542 & 50.037 & 0.439 & 50.468 & 1.271 & 56.493 & 0.331 \\
\hline $\mathrm{V}_{2} \mathrm{O}_{3}$ & 0.053 & 0.028 & 0.100 & 0.043 & 0.157 & 0.027 & 0.060 & 0.040 & 0.074 & 0.045 \\
\hline $\mathrm{Fe}_{2} \mathrm{O}_{3}$ & 5.907 & 0.219 & 4.473 & 0.360 & 7.247 & 0.413 & 4.638 & 0.213 & 7.180 & 0.286 \\
\hline $\mathrm{FeO}$ & 17.973 & 0.352 & 17.771 & 0.382 & 23.008 & 0.807 & 20.741 & 0.357 & 25.211 & 0.182 \\
\hline $\mathrm{MnO}$ & 0.151 & 0.035 & 0.153 & 0.045 & 0.255 & 0.053 & 0.183 & 0.036 & 0.406 & 0.035 \\
\hline $\mathrm{MgO}$ & 11.061 & 0.262 & 11.266 & 0.230 & 7.983 & 0.533 & 9.365 & 0.222 & 4.573 & 0.084 \\
\hline $\mathrm{NiO}$ & 0.096 & 0.026 & 0.094 & 0.045 & 0.080 & 0.043 & 0.129 & 0.015 & 0.050 & 0.021 \\
\hline $\mathrm{CaO}$ & 0.012 & 0.008 & 0.007 & 0.008 & 0.006 & 0.009 & 0.007 & 0.006 & 0.016 & 0.010 \\
\hline $\mathrm{ZnO}$ & 0.123 & 0.078 & 0.154 & 0.115 & 0.200 & 0.075 & 0.154 & 0.096 & 0.529 & 0.109 \\
\hline TOT & 101.387 & 0.357 & 101.513 & 0.370 & 101.600 & 0.401 & 101.709 & 0.593 & 100.519 & 0.319 \\
\hline $\mathrm{Ti}$ & 0.015 & 0.001 & 0.014 & 0.001 & 0.016 & 0.002 & 0.014 & 0.000 & 0.002 & 0.001 \\
\hline $\mathrm{Al}$ & 0.528 & 0.014 & 0.561 & 0.013 & 0.515 & 0.010 & 0.580 & 0.027 & 0.243 & 0.003 \\
\hline $\mathrm{Cr}$ & 1.296 & 0.019 & 1.301 & 0.016 & 1.284 & 0.010 & 1.278 & 0.032 & 1.561 & 0.008 \\
\hline $\mathrm{V}$ & 0.001 & 0.001 & 0.003 & 0.001 & 0.004 & 0.001 & 0.002 & 0.001 & 0.002 & 0.001 \\
\hline $\mathrm{Fe}^{3+}$ & 0.142 & 0.005 & 0.107 & 0.008 & 0.177 & 0.010 & 0.112 & 0.005 & 0.189 & 0.007 \\
\hline $\mathrm{Fe}^{2+}$ & 0.480 & 0.010 & 0.471 & 0.011 & 0.625 & 0.024 & 0.555 & 0.009 & 0.737 & 0.005 \\
\hline $\mathrm{Mn}$ & 0.004 & 0.001 & 0.004 & 0.001 & 0.007 & 0.001 & 0.005 & 0.001 & 0.012 & 0.001 \\
\hline $\mathrm{Mg}$ & 0.527 & 0.011 & 0.533 & 0.010 & 0.386 & 0.025 & 0.447 & 0.011 & 0.238 & 0.004 \\
\hline $\mathrm{Ni}$ & 0.002 & 0.001 & 0.002 & 0.001 & 0.002 & 0.001 & 0.003 & 0.000 & 0.001 & 0.001 \\
\hline $\mathrm{Ca}$ & 0.000 & 0.000 & 0.000 & 0.000 & 0.000 & 0.000 & 0.000 & 0.000 & 0.001 & 0.000 \\
\hline $\mathrm{Zn}$ & 0.003 & 0.002 & 0.004 & 0.003 & 0.005 & 0.002 & 0.004 & 0.002 & 0.014 & 0.003 \\
\hline $\mathrm{XCr}$ & 0.711 & 0.008 & 0.699 & 0.007 & 0.714 & 0.005 & 0.688 & 0.015 & 0.866 & 0.002 \\
\hline $\mathrm{XMg}$ & 0.523 & 0.010 & 0.531 & 0.010 & 0.382 & 0.024 & 0.446 & 0.010 & 0.244 & 0.004 \\
\hline
\end{tabular}

Variation in $\mathrm{XMg}$ and $\mathrm{XCr}$ in chromites is also demonstrated to be dependent on the nature of the host rock (Figure 3).

Chromitite Cr-spinels have the highest XMg, with averages of 0.523 for Rio Creves and 0.531 for Polunia, and average XCr of 0.711 and 0.699 , respectively.

CHD Cr-spinels have average XMg variable between 0.382 (Rio Creves) and 0.443 (Polunia), and average XCr of 0.714 (Rio Creves) and 0.688 (Polunia).

CFD Cr-spinels have considerably lower XMg (0.244 on average), and high XCr (0.866). 


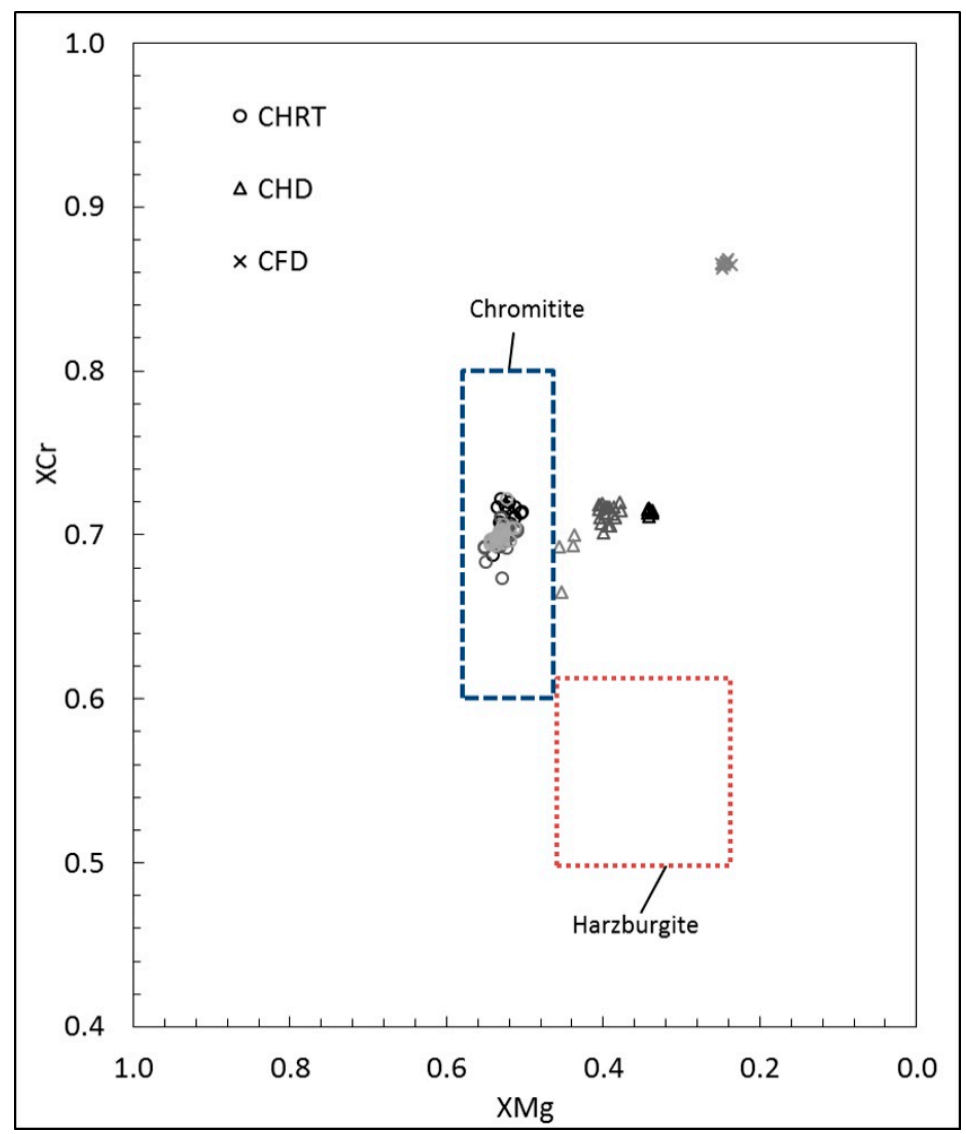

Figure 3. $\mathrm{XCr}$ vs. $\mathrm{XMg}$ values of spinels in three lithologies (CHRT: chromitite; CHD: chromitite-hosting dunite; CFD: chromitite-free dunite) compared to Finero harzburgite and chromitite compositional fields. Harzburgite data are from Grieco et al. [18]; chromitite data are from Zanetti et al. [21].

\subsection{Olivine Mineral Chemistry}

Olivine mineral chemistry (Table 2, with average compositions represented by grain core analyses), also shows chemical variation dependent on the type of host rock.

In chromitites, olivine is strongly forsteritic, with a high $\mathrm{MgO}$ content (50.59-54.78 wt \%) and low $\mathrm{FeO}(4.70-6.40 \mathrm{wt} \%)$. Average $\mathrm{XMg}$ is 0.942 for both localities.

Olivines in CHD show slightly lower $\mathrm{MgO}$ content (49.50-51.50 wt \%) and higher $\mathrm{FeO}$ (6.90-8.60 wt \%), resulting in a lower XMg, with an average of 0.917 for Rio Creves and 0.926 for Polunia.

Within CFD olivine, $\mathrm{MgO}$ content is even lower (48.48-49.67 wt \%) and $\mathrm{FeO}$ is the highest $(8.26-8.70 \mathrm{wt} \%)$. The average $\mathrm{XMg}$ is 0.912 .

Olivine trace element composition also varies with the type of host rock; $\mathrm{Mn}$ and $\mathrm{Ni}$ are particularly sensitive. For the other trace elements, standard deviation is too high to infer any reliable pattern.

$\mathrm{Ni}$ is the most abundant trace element in olivines, and is variable between 2079 and $4626 \mathrm{ppm}$ (average of 3163 ppm) in chromitites, 1807 and 4207 ppm in CHD (average of 2560) and 1959 and $3352 \mathrm{ppm}$ in CFD (average of 2915). Mn has low concentration in chromitites (154-1170 ppm, with an average of 725), increasing abundance in CHD (380-1425 ppm, with an average of 965) and the highest concentration in CFD (638-1556 ppm, with an average of 1168). 
Table 2. Major and trace elements average content and standard deviation of olivine cores from Rio Creves and Alpe Polunia, for the three host rocks: chromitite, CHD, CFD.

\begin{tabular}{|c|c|c|c|c|c|c|c|c|c|c|}
\hline \multicolumn{11}{|c|}{ Olivine Core Analyses } \\
\hline \multirow{4}{*}{$\begin{array}{l}\text { Sample } \\
\text { Elem }\end{array}$} & \multicolumn{4}{|c|}{ Chromitite } & \multicolumn{4}{|c|}{ CHD } & \multirow{2}{*}{\multicolumn{2}{|c|}{$\begin{array}{c}\text { CFD } \\
\text { DUN-FIN }\end{array}$}} \\
\hline & \multicolumn{2}{|c|}{ FIN01A } & \multicolumn{2}{|c|}{ PO4A } & \multicolumn{2}{|c|}{ FIN02B } & \multicolumn{2}{|c|}{ PO4A } & & \\
\hline & Avg. & St. Dev. & Avg. & St. Dev. & Avg. & St. Dev. & Avg. & St. Dev. & Avg. & St. Dev. \\
\hline & 40.876 & 0.253 & 41.572 & 0.356 & 41.162 & 0.456 & 41.289 & 0.183 & 40.805 & 0.196 \\
\hline $\mathrm{TiO}_{2}$ & 0.010 & 0.015 & 0.013 & 0.020 & 0.013 & 0.018 & 0.023 & 0.027 & 0.018 & 0.017 \\
\hline $\mathrm{Al}_{2} \mathrm{O}_{3}$ & 0.004 & 0.009 & 0.008 & 0.012 & 0.006 & 0.008 & 0.005 & 0.009 & 0.006 & 0.007 \\
\hline $\mathrm{Cr}_{2} \mathrm{O}_{3}$ & 0.017 & 0.024 & 0.015 & 0.020 & 0.024 & 0.032 & 0.015 & 0.020 & 0.029 & 0.031 \\
\hline $\mathrm{V}_{2} \mathrm{O}_{3}$ & 0.012 & 0.017 & 0.007 & 0.011 & 0.011 & 0.016 & 0.011 & 0.013 & 0.013 & 0.014 \\
\hline $\mathrm{Fe}_{2} \mathrm{O}_{3}$ & 0.000 & 0.000 & 0.000 & 0.000 & 0.000 & 0.000 & 0.000 & 0.000 & 0.000 & 0.000 \\
\hline $\mathrm{FeO}$ & 5.678 & 0.354 & 5.689 & 0.386 & 8.168 & 0.237 & 7.260 & 0.130 & 8.472 & 0.164 \\
\hline $\mathrm{MnO}$ & 0.079 & 0.032 & 0.075 & 0.031 & 0.128 & 0.028 & 0.116 & 0.033 & 0.158 & 0.032 \\
\hline $\mathrm{MgO}$ & 51.339 & 0.427 & 52.124 & 0.644 & 50.410 & 0.347 & 50.860 & 0.271 & 48.994 & 0.327 \\
\hline $\mathrm{NiO}$ & 0.346 & 0.047 & 0.465 & 0.050 & 0.321 & 0.041 & 0.452 & 0.039 & 0.375 & 0.049 \\
\hline $\mathrm{ZnO}$ & 0.048 & 0.038 & 0.024 & 0.042 & 0.035 & 0.048 & 0.030 & 0.055 & 0.040 & 0.042 \\
\hline TOT & 98.419 & 0.528 & 100.013 & 0.546 & 100.303 & 0.477 & 100.078 & 0.308 & 98.917 & 0.295 \\
\hline $\mathrm{Si}$ & 1.000 & 0.004 & 1.001 & 0.010 & 0.999 & 0.009 & 1.001 & 0.005 & 1.008 & 0.006 \\
\hline $\mathrm{Ti}$ & 0.000 & 0.000 & 0.000 & 0.000 & 0.000 & 0.000 & 0.000 & 0.000 & 0.000 & 0.000 \\
\hline $\mathrm{Al}$ & 0.000 & 0.000 & 0.000 & 0.000 & 0.000 & 0.000 & 0.000 & 0.000 & 0.000 & 0.000 \\
\hline $\mathrm{Cr}$ & 0.000 & 0.000 & 0.000 & 0.000 & 0.000 & 0.001 & 0.000 & 0.000 & 0.001 & 0.001 \\
\hline $\mathrm{V}$ & 0.000 & 0.000 & 0.000 & 0.000 & 0.000 & 0.000 & 0.000 & 0.000 & 0.000 & 0.000 \\
\hline $\mathrm{Fe}^{3+}$ & 0.000 & 0.000 & 0.000 & 0.001 & 0.000 & 0.001 & 0.000 & 0.000 & 0.000 & 0.000 \\
\hline $\mathrm{Fe}^{2+}$ & 0.116 & 0.007 & 0.115 & 0.008 & 0.166 & 0.005 & 0.147 & 0.003 & 0.175 & 0.004 \\
\hline Mn & 0.002 & 0.001 & 0.002 & 0.001 & 0.003 & 0.001 & 0.002 & 0.001 & 0.003 & 0.001 \\
\hline $\mathrm{Mg}$ & 1.873 & 0.010 & 1.872 & 0.013 & 1.824 & 0.011 & 1.838 & 0.006 & 1.804 & 0.007 \\
\hline $\mathrm{Ni}$ & 0.007 & 0.001 & 0.009 & 0.001 & 0.006 & 0.001 & 0.009 & 0.001 & 0.007 & 0.001 \\
\hline $\mathrm{Zn}$ & 0.001 & 0.001 & 0.000 & 0.001 & 0.001 & 0.001 & 0.001 & 0.001 & 0.001 & 0.001 \\
\hline $\mathrm{XMg}$ & 0.942 & 0.004 & 0.942 & 0.004 & 0.917 & 0.003 & 0.926 & 0.001 & 0.912 & 0.002 \\
\hline
\end{tabular}

\section{3. $\mathrm{Mg}-\mathrm{Fe}^{2+}$ Zoning in Olivine and Spinel}

Data demonstrate a correlation of olivine and chromite $\mathrm{XMg}$ with distance from the grain boundary (Figure 4). All olivines display zonation approaching the adjacent chromite rim, with an increase in $\mathrm{XMg}$ of about 0.020 in specific grains. Chromites display a zonation only within relatively larger grains, more common in chromitites, with a $\Delta \mathrm{XMg}$ always $2-3$ times larger than the one in olivines, but with a higher scatter of data, possibly due to $\mathrm{Fe}^{2+}-\mathrm{Fe}^{3+}$ repartitioning. Disseminated spinels in dunite generally lack compositional zonation. A single exception to this homogeneity was identified within a CHD at Polunia (PO4A-GRID3) that shows a visible zonation trend in XMg.

Olivines in chromitite samples possess recognizable zonation as far as $0.1 \mathrm{~mm}$ from their grain boundary. Zonation in spinels is restricted to the first $0.05 \mathrm{~mm}$ from the boundary. Within dunites, the only chromite that shows any compositional zoning has a variation in XMg within $0.015 \mathrm{~mm}$ from its rim. Olivine $\mathrm{XMg}$ zoning extends as far as $0.03 \mathrm{~mm}$ within the olivine from its grain boundary. 


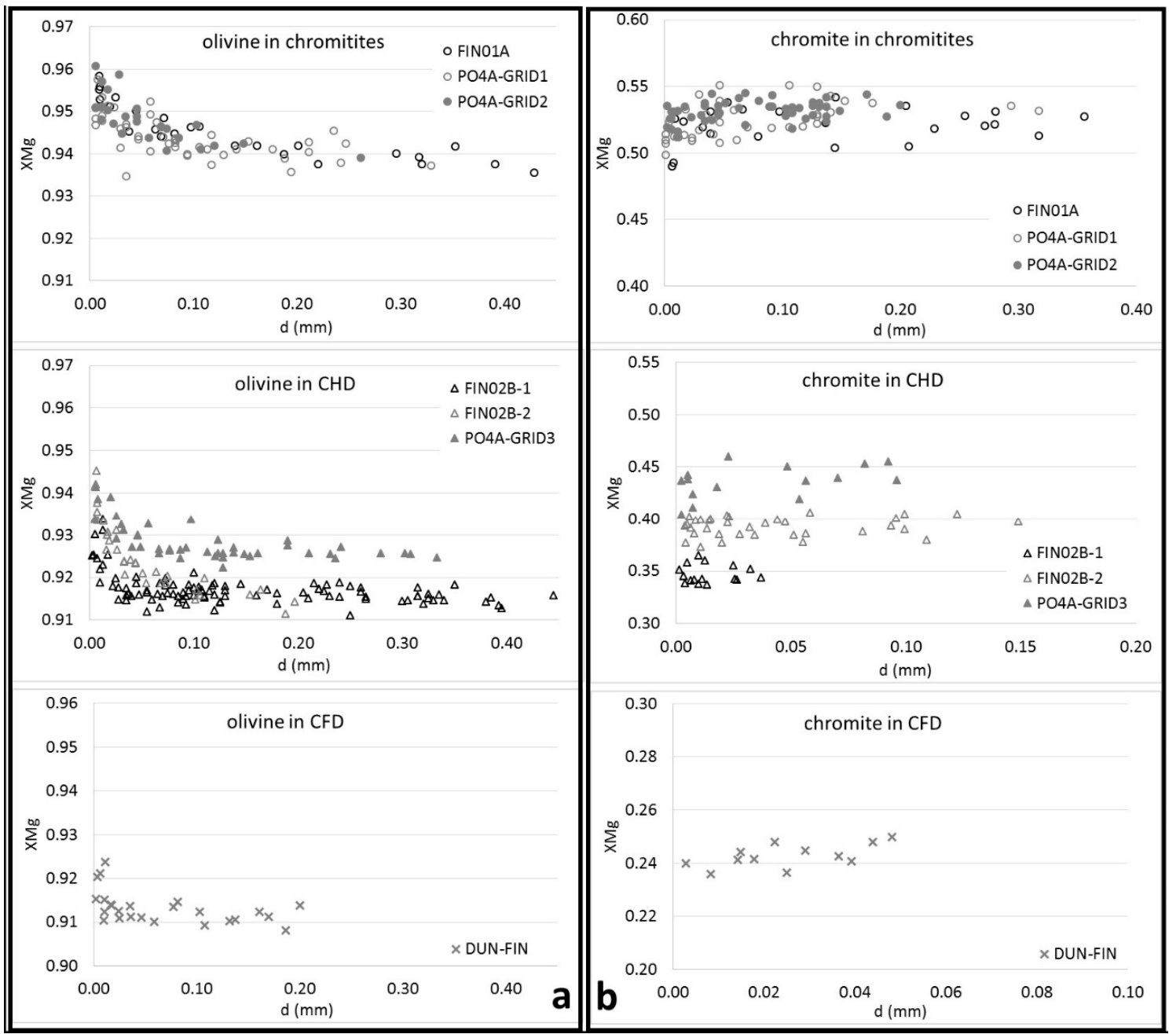

Figure 4. XMg vs. distance from the grain boundary ( $\mathrm{mm}$ ) of olivines (a) and chromites (b) in three host rocks and seven different microareas.

\section{Discussion}

\subsection{Olivine-Spinel Re-Equilibration}

The potential $\mathrm{Mg}-\mathrm{Fe}^{2+}$ subsolidus exchange between spinel and silicate phases (olivine, and/or pyroxene) is important. Mineralogical and experimental data show a high $\mathrm{Mg}-\mathrm{Fe}$ diffusivity in olivine and spinel [6,22], resulting in a low closure temperature of the system. Recent studies report low-temperature diffusivity experimental data down to $750{ }^{\circ} \mathrm{C}$ [23,24]; however, Méducin et al. [25] report that $\mathrm{Mg}$ and $\mathrm{Fe}^{2+}$ are still significantly disordered down to temperatures as low as $600{ }^{\circ} \mathrm{C}$. Incomplete exchange can give cause to compositional heterogeneity in these mineral phases: incomplete exchange is itself dependent on interdiffusivity coefficients and temperature $[2,8,26]$. In order to evaluate the exchange, olivine and spinels in unaltered (serpentine-free) chromitites, chromitite-hosting dunites and chromitite-free dunites were analyzed.

Irvine [1] was the first to link the chemical composition of these phases to the equilibrium constant of the exchange reaction $\left(\mathrm{K}_{\mathrm{d}}\right)$, and to use its temperature dependence to estimate coexisting olivine and spinel equilibrium temperature. The correlation between $K_{d}$ and temperature [1-4] results in the typical olivine and spinel diffusion profiles developed during cooling [8]. These profiles show that olivine is more magnesian close to the grain boundary, whereas magnesium in chromite grains decreases close to the rim. $\mathrm{Fe}^{2+}$ demonstrates the opposite trends, and hence $\mathrm{XMg}$ better reveals diffusivity patterns. 
At high temperature subsolidus conditions, diffusivity is sufficiently efficient to ensure a homogeneous spinel that is in equilibrium with surrounding olivine. With decreasing temperature, the diffusion profile reflects lower diffusivity to the point where elemental exchange can no longer proceed [8]. This critical temperature is relatively low compared to other exchange reactions used as geothermometers in peridotites. Ca-Mg partitioning in pyroxenes or $\mathrm{Mg}-\mathrm{Fe}^{2+}$ exchange between orthopyroxene and spinel are stopped at higher temperatures [3,5-7]. This implies that $\mathrm{Fe}-\mathrm{Mg}$ distribution for olivine-spinel exchange is more sensitive to cooling, and records lower temperatures.

Evidence of chromites' XMg variability in other geological contexts (e.g., Oman chromitites) suggest that the zoning could be due to other factors apart from re-equilibration with a silicate phase. In particular, Borisova et al. [27] observed a first chromite generation crystallized in subsolidus conditions at temperatures between 600 and $950{ }^{\circ} \mathrm{C}$, overgrown by a second generation formed by fractional crystallization at higher temperatures. However, in Finero, there is no mineralogical evidence of more than one chromite generation, as $\mathrm{XCr}$ values are homogeneous. The $\mathrm{XMg}$ zoning is continuous through the crystals, and the mirror patterns within olivines are indicative of diffusivity between the two phases.

The possibility that diffusion patterns were induced by a secondary fluorescence effect has also been considered and discarded. Secondary fluorescence effects in microprobe analyses are important when considering trace element concentrations measured in a mineral that coexists with another phase containing the element of interest [28,29]. Trace element concentration in this case is overestimated at the rim, producing a profile similar to the diffusivity one. Both $\mathrm{Mg}$ and $\mathrm{Fe}$ are major components of Finero chromites and olivines, so that secondary fluorescence effects can be neglected. Moreover, a secondary fluorescent effect would result in fictitious $\mathrm{XMg}$ values, higher in the chromite rim and lower in the olivine rim, which is the opposite of what was observed. In addition, the lack of a pattern within dispersed spinels suggests that secondary fluorescence effects, if they are present, produce a variability lower than the dispersion of the analyses.

\subsection{Re-Equilibration and Primary Composition Assessment through Diffusivity Curve Analysis}

Olivine and spinel compositions at grain boundaries reflect the critical temperature below which subsolidus exchange cannot proceed. Within the cores of mineral grains, in particular in the cores of larger-sized grains, minerals appear to retain their primary composition, which can be used to estimate their primary crystallization temperature.

The composition of mineral rims is usually determined through arithmetic mean of several coupled analyses, within 10-20 $\mu \mathrm{m}$ from the grain boundary. As calculated XMg diffusion pattern follows an exponential trend [8,9], confirmed by Finero data (Figure 4), estimates of the true rim compositions are very sensitive to distance from the grain boundary. XMg diffusivity patterns in the Finero samples are restricted to distances of less than $100 \mu \mathrm{m}$ from the rim: the highest variability is observed within the initial few tens of microns from the grain rims. The use of a simple arithmetic mean as a composition leads to $\mathrm{XMg}$ overestimation for spinel rim compositions and underestimation for olivine, hence producing equilibrium temperature assessments higher than actual rim equilibrium conditions.

Our approach is based on the determination of a "best-fit" correlation curve, and then used to calculate rim and core $\mathrm{XMg}$ values. Assumptions for this approach are an initial homogeneous composition of both olivine and chromite (primary composition) at the point of their original crystallization, and a finite value of $\mathrm{XMg}$ at the rim imparted during re-equilibration. $\mathrm{XMg}$ value as a function of distance from the grain boundary is modelled to fit the dataset following two boundary conditions. Setting $x=0$ at the chromite-olivine grain boundary and $\mathrm{XMg}=\mathrm{f}(x)$, these conditions are:

$$
\lim _{x \rightarrow \infty} f(x)=X M g_{p r}
$$


(The curve must approach an asymptote corresponding to $\mathrm{XMg}_{\mathrm{pr}}$, the primary $\mathrm{XMg}$ ).

$$
\lim _{x \rightarrow 0} f(x)=X M g_{\text {eq }}
$$

(The curve must have an intercept corresponding to $\mathrm{XMg}$ eq, the re-equilibrated $\mathrm{XMg}$ ).

The diffusivity curve was fitted with an exponential Function (3) using OriginLab software as follows:

$$
y=a-b c^{x},\left[X M g=y ; X M g r r=a ; X M g_{e q}=(a-b)\right] .
$$

In this manner, diffusivity curves were modelled for four spinel and seven olivine data sets (Table 3, Figure 5). For three other spinel datasets, without a clear diffusivity pattern, the average XMg was assumed to represent equilibrium composition.

The standard error values (Table 3) reveal that most of the inferred parameters are reliable. The higher error for chromites is probably due to $\mathrm{Fe}^{2+}-\mathrm{Fe}^{3+}$ partitioning. Standard error is always low for $\mathrm{XMg}_{\mathrm{pr}}$ (associated to parameter " $a$ "), and it is relatively high for $\mathrm{XMg}_{\text {eq }}$ only for two chromite data due to parameter " $b$ " error.

Table 3. Parameters $a, b, c$ and associated standard error of calculated curves and primary (pr) and re-equilibrated (eq) $\mathrm{XMg}$ atomic ratios of chromites and olivines for three host rocks.

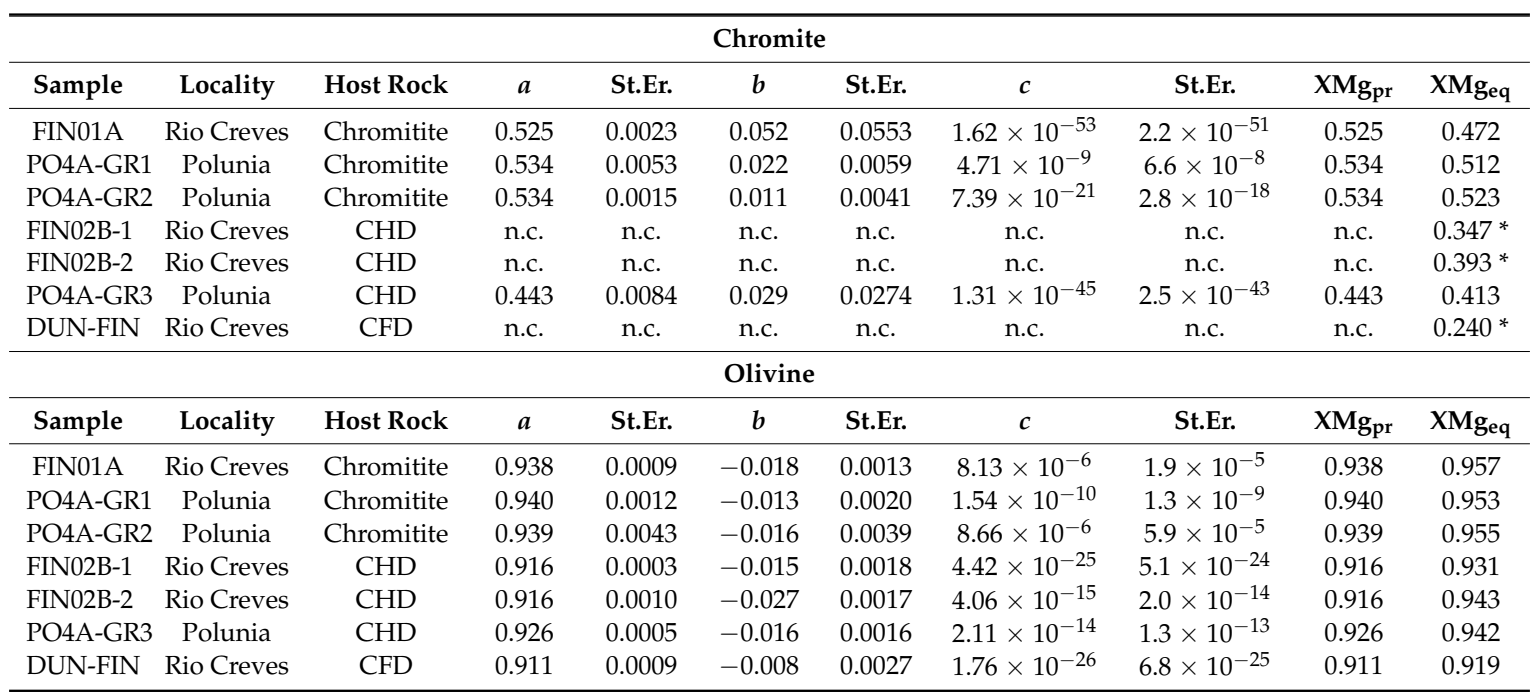

* Calculated as average XMg value; n.c. not computable.

The computation of primary and re-equilibrated XMg values of olivine is always possible since its original composition is dependent on the crystal grain size; olivine grain sizes in the sample set are sufficient large even in massive chromitites. The original $\mathrm{XMg}$ within chromites was computed in all our chromitite samples but was possible only for one dunite sample. In dunites, small, disseminated chromite grains within the olivine matrix are always completely re-equilibrated and only one grain was large enough to allow $\mathrm{XMg}_{\mathrm{pr}}$ computation. The exponential curves thus modelled provide also an estimate of a diffusion distance beyond which there is no more subsolidus exchange. For olivines, curves are smooth and the diffusion distance is comprised between 0.08 and $0.20 \mathrm{~mm}$, with the highest values in chromitites. Chromite curves are more abrupt, and the diffusion distance ranges between 0.04 and $0.20 \mathrm{~mm}$ in chromitite samples. The only diffusion distance value of chromite in dunites is $0.06 \mathrm{~mm}$. Diffusion distance values confirm that a simple arithmetic mean approach cannot be applied in Finero. 


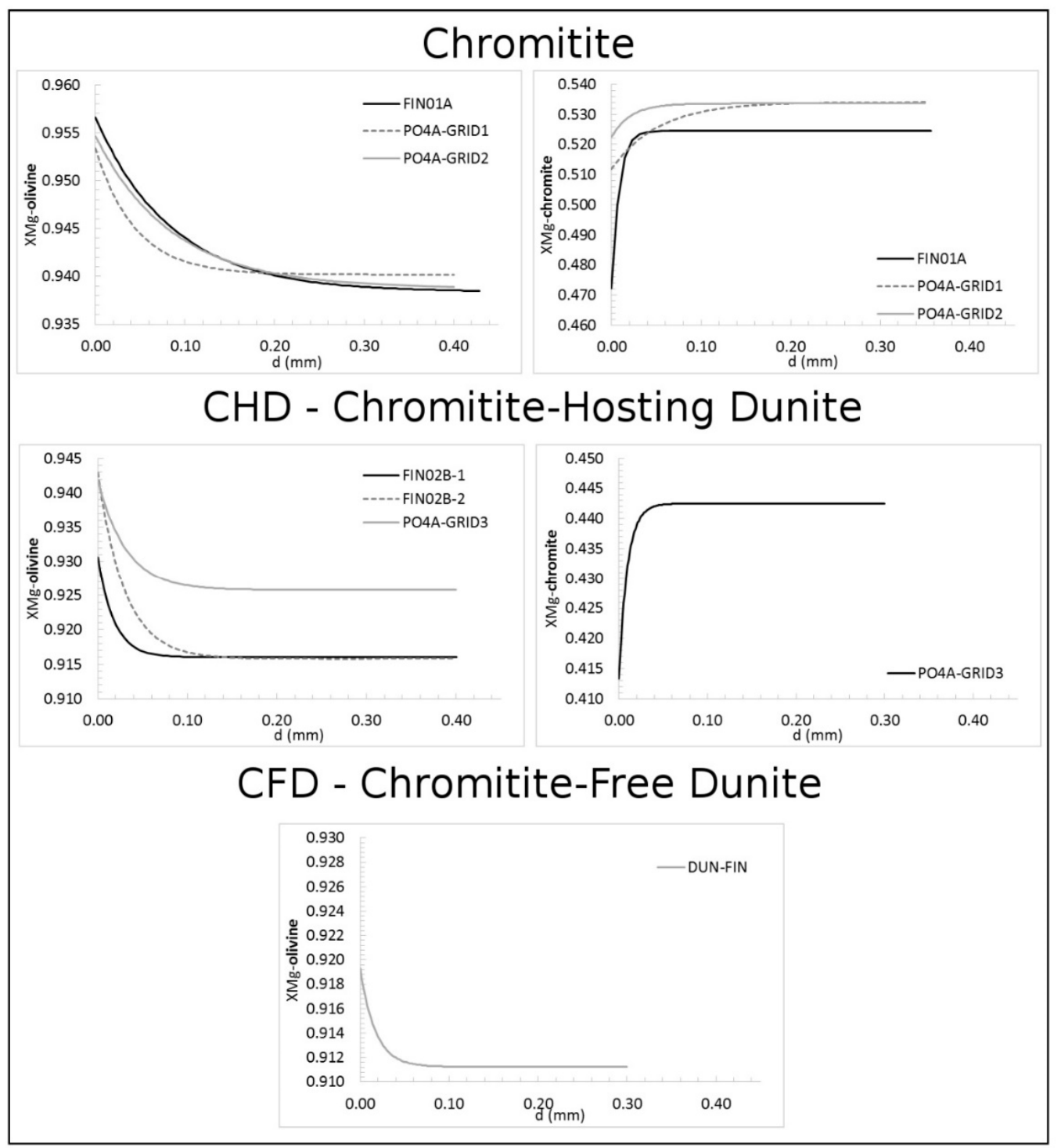

Figure 5. Diffusivity curves determined for olivines and chromites in three host rocks through OriginLab software; $\mathrm{d}(\mathrm{mm})$ : distance from the grain boundary.

\subsection{Geothermometry}

Geothermometry of olivine-spinel exchange applied to rim-rim analyses has been repeatedly used to estimate the thermometric cessation of elemental exchange conditions. Core-core analyses are cited in the literature as a means to determine the original mineralogic compositions of olivine-chromite pairs [6]. The assumption that core compositions retain their primary imprint, however, is not always true. In fact, it is dependent on chromite modal content [11], and spinel grain size [8,9].

Temperature estimates were applied to re-equilibrated and primary $\mathrm{XMg}$ values following Ballhaus et al. [4] calibration (Table 4). The olivine-spinel re-equilibrated temperatures range between 694 and $715{ }^{\circ} \mathrm{C}$ within chromitites, with an average of $707^{\circ} \mathrm{C}$, between 657 and $675{ }^{\circ} \mathrm{C}$ in $\mathrm{CHD}$ (average value $666^{\circ} \mathrm{C}$ ) and only a single re-equilibration temperature of $656^{\circ} \mathrm{C}$ could be estimated from the CFD sample. The Rio Creves locality shows an average re-equilibration temperature of $667^{\circ} \mathrm{C}$, while Polunia has a slightly higher average temperature $\left(694^{\circ} \mathrm{C}\right)$. Primary temperatures in chromitites range between 812 and $849{ }^{\circ} \mathrm{C}$, with an average of $826^{\circ} \mathrm{C}$. Within CHD from Polunia, the only computed primary temperature is $753^{\circ} \mathrm{C}$. The Rio Creves locality has the highest primary temperature value $\left(849^{\circ} \mathrm{C}\right)$, while Polunia shows an average primary temperature of $794^{\circ} \mathrm{C}$. 
Table 4. Primary and re-equilibration temperatures (respectively $\mathrm{T}_{\mathrm{pr}}$ and $\mathrm{T}_{\mathrm{eq}}$ ) following Ballhaus et al. [4] calibration. (n.c.-not-computable).

\begin{tabular}{cclcc}
\hline Sample & Locality & Lithology & $\mathbf{T}_{\mathbf{p r}}\left({ }^{\circ} \mathbf{C}\right)$ & $\mathbf{T}_{\text {eq }}\left({ }^{\circ} \mathbf{C}\right)$ \\
\hline FIN01A & Rio Creves & chromitite & 849 & 694 \\
PO4A-GR1 & Polunia & chromitite & 812 & 713 \\
PO4A-GR2 & Polunia & chromitite & 817 & 715 \\
FIN02B-1 & Rio Creves & CHD & n.c. & 657 \\
FIN02B-2 & Rio Creves & CHD & n.c. & 675 \\
PO4A-GR3 & Polunia & CHD & 753 & 662 \\
DUN-FIN & Rio Creves & CFD & n.c. & 656 \\
\hline
\end{tabular}

Re-equilibration temperatures record the closing temperatures of the subsolidus mineral exchange system. Within peridotites, olivine-spinel is the system that "freezes" last with decreasing temperatures, allowing a determination of the thermal history of the rocks down to $\sim 650{ }^{\circ} \mathrm{C}$.

Primary temperatures represent the threshold temperatures below which diffusivity cannot maintain compositional homogeneity within the crystals $[1,3,6,7]$.

\subsection{Cooling Rates}

$\mathrm{Mg}-\mathrm{Fe}^{2+}$ zoning used to infer primary and re-equilibrated compositions and temperatures can also be used to estimate a cooling rate in ultramafic rocks [8,9]. In particular, spinel XMg appears to be more sensitive to cooling rate differences than olivine $\mathrm{XMg}$, especially at low rates within the range of $\sim 850-\sim 650{ }^{\circ} \mathrm{C}$. Ozawa [9] calculated cooling rate profiles for several types of natural rocks at different initial temperatures of the system, numerically solving the differential equations that describe the $\mathrm{Mg}-\mathrm{Fe}^{2+}$ exchange system of a spherical spinel surrounded by olivine. His solution reveals a relationship between temperature and spinel grain diameter. Temperatures in his model are neither primary nor re-equilibrated, but calculated using spinel and olivine $\mathrm{XMg}$ core analyses. In these estimates, olivine $\mathrm{XMg}$ coincides with the primary value but not in chromite: this equivalence it is valid only for grains with a radius larger than diffusion distance.

Figure 6 is a semi-logarithmic plot of grain diameter vs. $\mathrm{T}\left({ }^{\circ} \mathrm{C}\right)$ : it results in a function with two knees and two asymptotes. The asymptote at higher temperatures reflects the presence of non re-equilibrated core areas for larger grains that apparently preserve the primary composition. The asymptote at lower temperatures is a mathematical construct that reflects the re-equilibrated areas approaching the grain boundary $(\mathrm{d} \rightarrow 0)$. The steeper portion of the curve is ascribed to the cooling rates of the rocks. These trends follow constant cooling rate curves or, when they deviate from these patterns, imply a variable cooling rate. Thus, a deviation within the dataset plot indicates a change in cooling rate conditions, as often happens for natural systems. Smooth, near horizontal trends can be explained both by a low initial temperature and a change in cooling conditions from lower to higher cooling rates with decreasing temperature. Published studies demonstrate cooling rates for the Iwanaidake peridotites to be on the order of $10^{-4}-10^{-1}{ }^{\circ} \mathrm{C} / \mathrm{yr}$, while, for extrusive rocks such as picrites, cooling rates are estimated at $10^{3}$ to $10^{4}{ }^{\circ} \mathrm{C} / \mathrm{yr}[9]$.

Finero diffusion curves derived within our study were redrawn assuming that the diameter of spinel grains (as considered by Ozawa [9]), is equivalent to two times the distance from the grain boundary (d). These were then compared to constant cooling rate profiles compatible with presumed Finero conditions (initial temperature $<900{ }^{\circ} \mathrm{C}$, pressure 0.9-1.1 GPa, Figure 6).

Our results indicate that Finero cooling rates are between $10^{-4}{ }^{\circ} \mathrm{C} / \mathrm{yr}$ and $10^{-2}{ }^{\circ} \mathrm{C} / \mathrm{yr}$, corresponding to the steeper portion of the S-shaped curves of Figure 6. Only one curve suggests slower cooling rates (FIN01A, $10^{-3}-10^{-2}{ }^{\circ} \mathrm{C} / \mathrm{yr}$ ). These rates are within the range established for Japanese peridotites, but with a different slope. Peridotites of the Iwanaidake ophiolite have steep slopes, almost along constant cooling rate curves; Finero peridotites show gentle slopes, indicative of a rapid increase in cooling rate conditions between $\sim 850$ and $\sim 650^{\circ} \mathrm{C}$. 


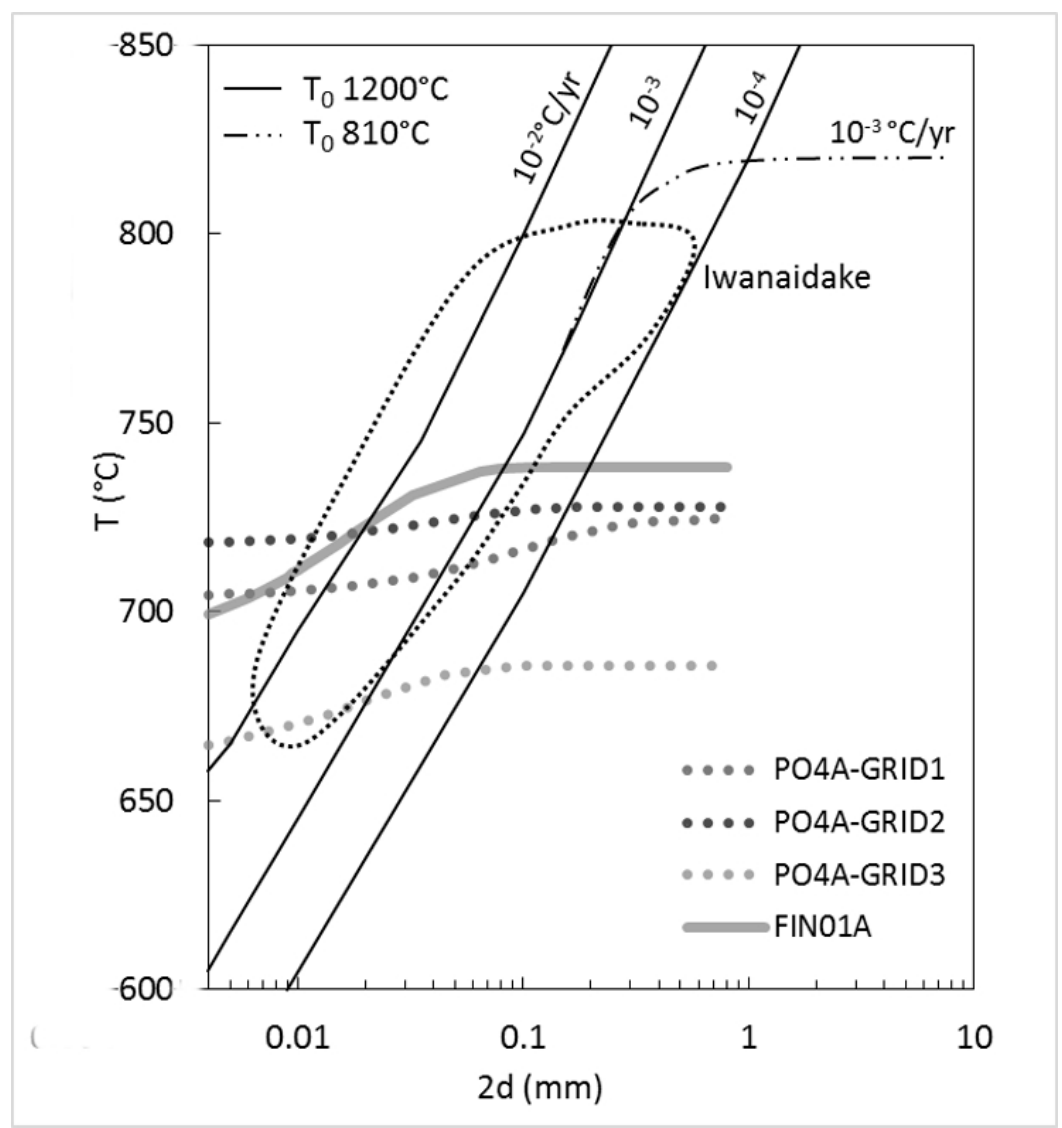

Figure 6. T $\left({ }^{\circ} \mathrm{C}\right)$ vs. 2D plot of Finero diffusion curves. Temperatures are calculated according to Fabriès [3], constant cooling rate curves and Iwanaidake peridotite field are from Ozawa [9]. $\mathrm{T}_{0}$ : initial temperature for the calculation of constant cooling rate curves.

\subsection{Finero Thermal History}

The thermal history of Finero massif has been established by various researchers datasets based on $\mathrm{U}-\mathrm{Pb}$ zircon ages [18,21,30], diffusion of $\mathrm{Pb}$ and $\mathrm{Zr}$ in rutile [31], geodynamical data [32], and petrographic-mineralogic data [33]. Diffusivity profiles can add an important contribution to the reconstruction of the thermal history of the massif.

Petrographic and chemical data suggest that at least two metasomatic events affected the Finero massif at different times $[18,34]$. During the first event estimated to the Permian, reactions between a mafic melt and surrounding harzburgites produced chromitite pods and associated dunites, as well as a suite of secondary mineralogical phases such as clinopyroxenes and amphiboles in the harzburgite. The second metasomatic event was characterized by the intrusion of clinopyroxenite dykes, followed by the infiltration in the harzburgite, along fractures, of a hydrous phase. The reaction between the water-rich fluid and the host rock produced phlogopite, the distinguishing feature of this second event.

The main metasomatic event that led to re-enrichment of the Finero body is still under debate. The volatile-rich fluids could have been derived from a crustal slab in a subduction setting [16,35]. A second possibility theorizes that fluids were derived from a mantle plume emplaced at the base of the subcontinental crust, in an extensional tectonic setting [15,17].

Chromitites and their dunite host bodies are generally accepted to have formed by metasomatic interaction of basic melts with surrounding harzburgite [18], during an early Permian underplating event (288 $\pm 7 \mathrm{Ma}$ [30]). Following the Permian event, peculiar P-T conditions caused a re-heating that re-equilibrated the U-Pb system [31]: this resulted in a large time span documented by zircon ages within the matrix of chromitites dating from Late Triassic to Early Jurassic $[18,21,30]$. The absence of 
melting in this time span suggests an upper limit to the maximum temperature of this re-heating event at $965{ }^{\circ} \mathrm{C}$, that is, the solidus estimated for Finero harzburgites [33].

The continuous cooling profile shown by our diffusivity data, without evidence of re-heating patterns suggests that there was no re-heating condition of the rocks, and is in agreement with a model requiring simple cooling from the high Permian temperatures.

However, recent studies support the hypothesis of a long permanence, at least till Mesozoic time, of the Finero body at great depths, corresponding to 1 GPa [36], or 0.9-1.1 GPa [37,38], based mainly on the reaction involving the formation of metamorphic sapphirine in gabbros of the Lower Internal Zone. Obtained cooling profiles can be better interpreted as due to complete re-setting of the olivine-spinel geothermometer. A long residence of the olivine-spinel system at temperatures just below the subsolidus completely re-homogenized olivine and spinel compositions. In this case, primary temperatures record the peak of the re-heating event at $849^{\circ} \mathrm{C}$, the highest primary temperature recorded. The Late Triassic chromitites zircon ages (208 Ma, [18]) thus date the time of the second thermal peak.

Exhumation of the Finero Complex initiated during the Early Jurassic $[21,32,33]$. The exhumation event was rapid, bringing the complex to a shallow to mid-crustal position. The extensional activity is concurrent to the opening of the Piemont Ocean. Exhumation was controlled by two major boundary faults, the Insubric Line and the Pogallo Line [32].

Finero olivine and spinel diffusion curves show that their re-equilibration is very limited. This limited re-equilibration could have been influenced by a low initial temperature and/or reflects the rapid, increasing with time, cooling rate. Cooling rates of $10^{-4}-10^{-2}{ }^{\circ} \mathrm{C} / \mathrm{yr}$, recorded at Finero agree with a rapid rate of exhumation to a shallow to mid-crustal position. This is a result similar to the one modelled for the Iwanaidake ophiolite of Japan [9].

The Ivrea Verbano Zone geotherm, estimated from geothermometric and geobarometric data determined for the amphibolite to granulite facies of rocks along the Strona Valley [32,39] is $22{ }^{\circ} \mathrm{C} / \mathrm{km}$ in the Permian. From the Permian onward, Finero cooling rates yield an initial exhumation velocity, in thermal equilibrium with the $22{ }^{\circ} \mathrm{C} / \mathrm{km}$ geotherm, of $0.45 \mathrm{~cm} / \mathrm{yr}$, which, with time, increased up to $45 \mathrm{~cm} / \mathrm{yr}$. The initial velocity is lower than the regional $2 \mathrm{~cm} / \mathrm{yr}$ tectonic uplift velocity [40] suggesting that initial uplift of Finero massif did not occur in equilibrium with the geothermal gradient. If the ascent occurred at the estimated $2 \mathrm{~cm} / \mathrm{yr}$ velocity and with a $10^{-4}{ }^{\circ} \mathrm{C} / \mathrm{yr}$ cooling rate, the uplift was almost adiabatic. Such exhumation conditions would provide supporting evidence for the Late Triassic thermal plume as a cause of the re-heating event. The increase of cooling rate up to $10^{-2}{ }^{\circ} \mathrm{C} / \mathrm{yr}$ results in an unrealistic $45 \mathrm{~cm} / \mathrm{yr}$ uplift. As such an exhumation ascent occurred after the thermal peak, the fast final cooling rate could be due to the combination of rapid uplift with decreasing geothermal gradient following the Late Triassic re-heating.

\subsection{Trace Elements Variation}

Analyses of trace element content in Cr-spinel ( $\mathrm{Ti}, \mathrm{Ni}, \mathrm{Zn}, \mathrm{Mn}, \mathrm{V})$ concentrations are listed in Table 1. These data, as well as major element contents $\left(\mathrm{Al}_{2} \mathrm{O}_{3}, \mathrm{MgO}, \mathrm{FeO}_{\text {(tot) }}\right.$ and $\left.\mathrm{Cr}_{2} \mathrm{O}_{3}\right)$, were normalized to the composition of the East Pacific Rise MORB [41] plotted so as to compare them with to chromites from different geological settings including the Bushveld layered intrusion [42] and Hellenic ophiolites [43]. The results of these comparative plots show similar patterns for chromitites and dunites, implying that the same petrological processes controlled trace elements contents.

Figure 7 is a plot of the Finero chromite and olivine trace element patterns. This plot is very similar to that of stratiform chromite, characterized by Ti and $\mathrm{Zn}$ enrichments. Differences concern mainly slightly higher Mn concentrations and a strong $\mathrm{V}$ depletion. In chromites, a variation of trace element content with the distance from the grain boundary demonstrates that $\mathrm{Ti}$ and, to a lesser extent $\mathrm{Ni}$, form clear patterns of a decrease towards the grain boundary (Figure 8). Anyway, mirror patterns in olivine are not present, suggesting that subsolidus exchange did not affect their contents. The homogeneity of Ni within olivine grains does not, however, imply a lack of subsolidus 
exchange with chromite: the higher $\mathrm{Ni}$ content in olivine could have obliterated the re-equilibration overprint. Ti does not partition into olivine [41], so zoning in chromite extending $0.4 \mathrm{~mm}$ from the grain rim is more probably due to primary crystallization processes that affected only spinels.

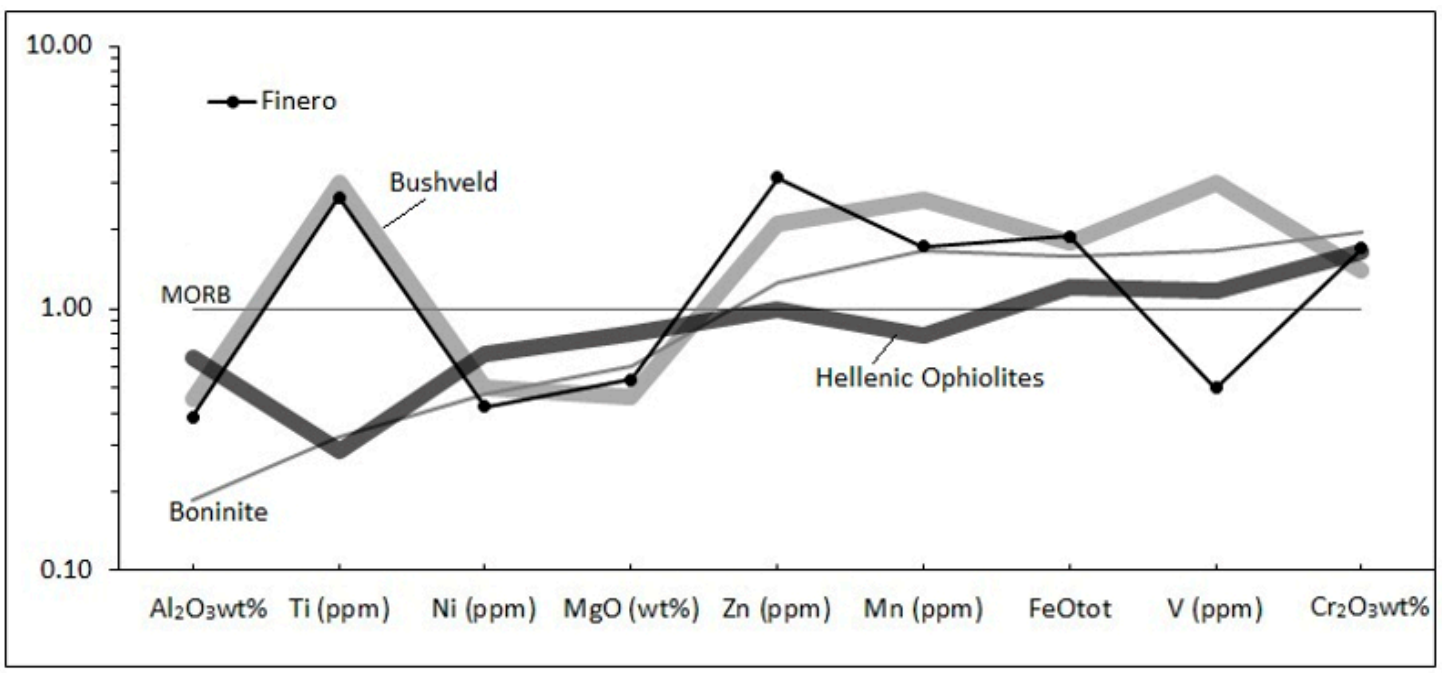

Figure 7. Trace elements pattern in chromites of the Finero Complex, normalized to MORB composition [41]. Podiform chromite pattern is from Hellenic ophiolites [43]. Stratiform chromite pattern is from Bushveld chromites [42].

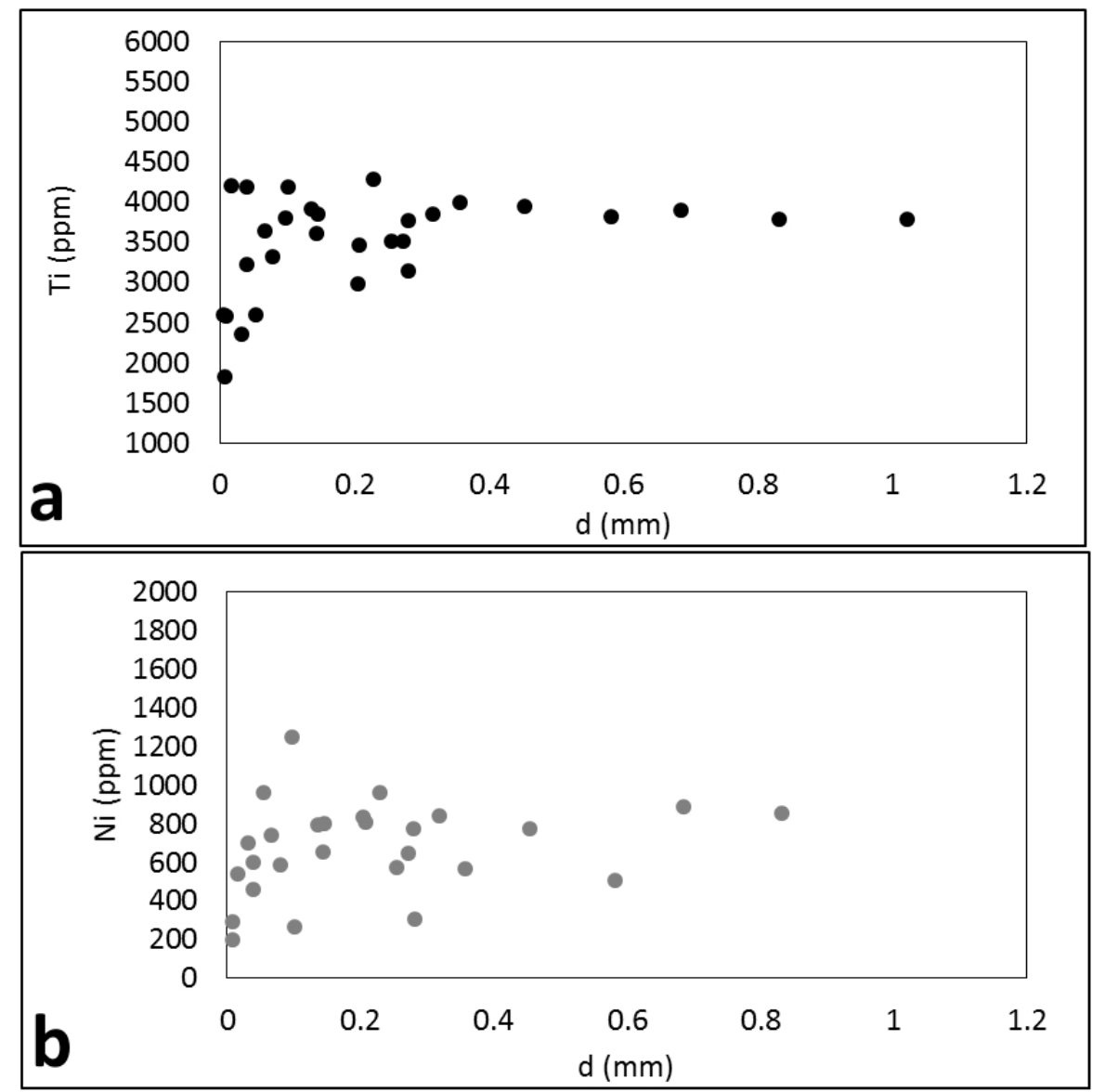

Figure 8. Ti (a) and $\mathrm{Ni}(\mathbf{b})$ concentrations vs. distance from grain boundary in chromites from Rio Creves chromitite. 


\section{Conclusions}

Olivine and chromite diffusivity patterns are useful tools for the reconstruction of the thermal history of chromitites and associated dunites down to at least $650^{\circ} \mathrm{C}$. The use of an exponential function to model $\mathrm{XMg}$ with distance from grain boundary minimizes potential error in the calculation of re-equilibrated and primary mineral compositions, producing more reliable temperature assessments.

An initial Early Permian metasomatic event was responsible for the formation of chromitite bodies and their host dunite within the Finero massif. This event is not recorded in chromite and olivine compositions as they were completely re-equilibrated during the Late-Triassic. Re-equilibration was caused by re-heating at temperatures up to $849^{\circ} \mathrm{C}$, just below the estimated $965^{\circ} \mathrm{C}$ solidus temperature. This thermal peak can be dated at $208 \mathrm{Ma}$, the age recorded by zircons in chromitite, as it completely reset the zircon U-Pb system. A subsequent exhumational uplift of Finero to a mid-crustal position occurred during the Early Jurassic rifting event at increasing cooling rates, demonstrated by re-equilibration temperatures. Rapid final cooling rates follow the cessation of the Jurassic thermal peak as the geothermal gradient was decreasing.

Supplementary Materials: The following are available online at http:/ /www.mdpi.com/2075-163X/9/2/75/s1.

Author Contributions: Conceptualization, M.B., G.G. and E.T.; Methodology, G.G.; Software, M.B.; Validation, M.B., G.G.; Formal Analysis, M.B.; Investigation, M.B., G.G., E.T.; Resources, G.G., E.T.; Data Curation, M.B.; Writing-Original Draft Preparation, M.B.; Writing-Review and Editing, G.G; Visualization, M.B.; Supervision, G.G.

Funding: This research received no external funding.

Acknowledgments: We wish to acknowledge the Italian Ministry of Education (MIUR) that partially supported this work through the project "Dipartimenti di Eccellenza 2017". We are grateful to Annie Ewing Rassios for revising the English language. The authors also wish to thank the reviewers for their helpful remarks.

Conflicts of Interest: The authors declare no conflict of interest.

\section{References}

1. Irvine, T.N. Chromian spinel as a petrogenetic indicator: Part 1. Theory. Can. J. Earth Sci. 1965, 2, 648-672. [CrossRef]

2. Irvine, T.N. Chromian spinel as a petrogenetic indicator: Part 2. Petrologic applications. Can. J. Earth Sci. 1967, 4, 71-103. [CrossRef]

3. Fabriès, J. Spinel-olivine geothermometry in peridotites from ultramafic complexes. Contrib. Mineral. Petrol. 1979, 69, 329-336. [CrossRef]

4. Ballhaus, C.; Berry, R.F.; Green, D.H. High pressure experimental calibration of the olivine-orthopyroxene-spinel oxygen geobarometer: Implications for the oxidation state of the upper mantle. Contrib. Mineral. Petrol. 1991, 107, 27-40. [CrossRef]

5. Lehmann, J. Diffusion between olivine and spinel: Application to geothermometry. Earth Planet. Sci. Lett. 1983, 64, 123-138. [CrossRef]

6. Greenfield, A.M.R.; Ghent, E.D.; Russell, J.K. Geothermobarometry of spinel peridotites from southern British Columbia: Implications for the thermal conditions in the upper mantle. Can. J. Earth Sci. 2013, 50, 1019-1032. [CrossRef]

7. Freer, R. Diffusion in silicate minerals and glasses: A data digest and guide to the literature. Contrib. Mineral. Petrol. 1981, 76, 440-454. [CrossRef]

8. Ozawa, K. Evaluation of Olivine-Spinel Geothermometry as an Indicator of Thermal History for Peridotites. Contrib. Mineral. Petrol. 1983, 82, 52-65. [CrossRef]

9. Ozawa, K. Olivine-spinel geospeedometry: Analysis of diffusion-controlled $\mathrm{Mg}-\mathrm{Fe}^{2+}$ exchange. Geochim. Cosmochim. Acta 1984, 48, 2597-2611. [CrossRef]

10. Sack, R.O.; Ghiorso, M.S. Chromian spinels as petrogenetic indicators: Thermodynamics and petrological applications. Am. Mineral. 1991, 76, 827-847.

11. Grieco, G.; Bussolesi, M.; Tzamos, E.; Rassios, A.E.; Kapsiotis, A. Processes of primary and re-equilibration mineralization affecting chromitite ore geochemistry within the Vourinos ultramafic sequence, Vourinos ophiolite (West Macedonia, Greece). Ore Geol. Rev. 2018, 95, 537-551. [CrossRef] 
12. Mehnert, K.R. The Ivrea Zone, a model of the deep crust. N. Jahrb. Miner. Abh. 1975, 125, 156-199.

13. Sinigoi, S.; Quick, J.E.; Clemens-Knott, D.; Mayer, A.; Demarchi, G.; Mazzucchelli, M.; Negrini, L.; Rivalenti, G. Chemical evolution of a large mafic intrusion in the lower crust, Ivrea-Verbano Zone, northern Italy. J. Geophys. Res. 1994, 99, 21559-21573. [CrossRef]

14. Coltorti, M.; Siena, F. Mantle tectonite and fractionate peridotite at Finero (Italian Western Alps). Neues Jahrb. fur Mineral. 1984, 149, 225-244.

15. Exley, R.A.; Sills, J.D.; Smith, J.V. Geochemistry of micas from the Finero spinel-lherzolite, Italian Alps. Contrib. Mineral. Petrol. 1982, 81, 59-63. [CrossRef]

16. Zanetti, A.; Mazzucchelli, M.; Rivalenti, G.; Vannucci, R. The Finero phlogopite-peridotite massif: An example of subduction-related metasomatism. Contrib. Mineral. Petrol. 1999, 134, 107-122. [CrossRef]

17. Garuti, G.; Bea, F.; Zaccarini, F.; Montero, P. Age, Geochemistry and Petrogenesis of the Ultramafic Pipes in the Ivrea Zone, NW Italy. J. Petrol. 2001, 42, 433-457. [CrossRef]

18. Grieco, G.; Ferrario, A.; Von Quadt, A.; Koeppel, V.; Mathez, E.A. The Zircon-Bearing Chromitites of the Phlogopite Peridotite of Finero (Ivrea Zone, Southern Alps): Evidence and Geochronology of a Metasomatized Mantle Slab. J. Petrol. 2001, 42, 89-101. [CrossRef]

19. Zaccarini, F.; Stumpfl, E.F.; Garuti, G. Zirconolite and Zr-Th-U minerals in chromitites of the Finero Complex, Western Alps, Italy: Evidence for carbonatite-type metasomatism in a subcontinental mantle plume. Can. Mineral. 2004, 42, 1825-1845. [CrossRef]

20. Whitney, D.L.; Evans, B.W. Abbreviations for names of rock-forming minerals. Am. Mineral. 2010, 95, 185-187. [CrossRef]

21. Zanetti, A.; Giovanardi, T.; Langone, A.; Tiepolo, M.; Wu, F.Y.; Dallai, L.; Mazzucchelli, M. Origin and age of zircon-bearing chromitite layers from the Finero phlogopite peridotite (Ivrea-Verbano Zone, Western Alps) and geodynamic consequences. Lithos 2016, 262, 58-74. [CrossRef]

22. Freer, R.; O'reilly, W. The Diffusion of $\mathrm{Fe}^{2+}$ Ions in Spinels with Relevance to the Process of Maghemitization. Mineral. Mag. 1980, 43, 889-899. [CrossRef]

23. Vogt, K.; Dohmen, R.; Chakraborty, S. Fe-Mg diffusion in spinel: New experimental data and a point defect model. Am. Mineral. 2015, 100, 2112-2122. [CrossRef]

24. Dohmen, R.; Becker, H.W.; Chakraborty, S. Fe-Mg diffusion in olivine I: Experimental determination between 700 and $1200{ }^{\circ} \mathrm{C}$ as a function of composition, crystal orientation and oxygen fugacity. Phys. Chem. Miner. 2007, 34, 389-407. [CrossRef]

25. Méducin, F.; Redfern, S.A.; Le Godec, Y.; Stone, H.J.; Tucker, M.G.; Dove, M.T.; Marshall, W.G. Study of cation order-disorder in $\mathrm{MgAl}_{2} \mathrm{O}_{4}$ spinel by in situ neutron diffraction up to $1600 \mathrm{~K}$ and $3.2 \mathrm{GPa}$. Am. Mineral. 2004, 89, 981-986. [CrossRef]

26. Medaris, L.G. Coexisting spinel and silicates in alpine peridotites of the granulite facies. Geochim. Cosmochim. Acta 1975, 39, 947-958. [CrossRef]

27. Borisova, A.Y.; Ceuleneer, G.; Kamenetsky, V.S.; Arai, S.; Béjina, F.; Abily, B.; Bindeman, I.N.; Polvé, M.; de Parseval, P.; Aigouy, T.; et al. A new view on the petrogenesis of the Oman ophiolite chromitites from microanalyses of chromite-hosted inclusions. J. Petrol. 2012, 53, 2411-2440. [CrossRef]

28. Llovet, X.; Galan, G. Correction of secondary X-ray fluorescence near grain boundaries in electron microprobe analysis: Application to thermobarometry of spinel lherzolites. Am. Mineral. 2003, 88, 121-130. [CrossRef]

29. Borisova, A.Y.; Zagrtdenov, N.R.; Toplis, M.J.; Donovan, J.J.; Llovet, X.; Asimow, P.D.; de Parseval, P.; Gouy, S. Secondary fluorescence effects in microbeam analysis and their impacts on geospeedometry and geothermometry. Chem. Geol. 2018, 490, 22-29. [CrossRef]

30. Badanina, I.Y.; Malitch, K.N.; Belousova, A. U-Pb and Hf isotope characteristics of zircon from chromites at Finero. In Proceedings of the Goldschmidt Abstracts 2013; Mineralogical Magazine; Mineralogical Society: London, UK, 2013; p. 639.

31. Smye, A.J.; Stockli, D.F. Rutile U-Pb age depth profiling: A continuous record of lithospheric thermal evolution. Earth Planet. Sci. Lett. 2014, 408, 171-182. [CrossRef]

32. Wolff, R.; Dunkl, I.; Kiesselbach, G.; Wemmer, K.; Siegesmund, S. Thermochronological constraints on the multiphase exhumation history of the Ivrea-Verbano Zone of the Southern Alps. Tectonophysics 2012, 579, 104-117. [CrossRef] 
33. Giovanardi, T.; Morishita, T.; Zanetti, A.; Mazzucchelli, M.; Vannucci, R. Igneous sapphirine as a product of melt-peridotite interactions in the Finero Phlogopite-Peridotite Massif, Western Italian Alps. Eur. J. Mineral. 2013, 25, 17-31. [CrossRef]

34. Grieco, G.; Ferrario, A.; Mathez, E.A. The effect of metasomatism on the Cr-PGE mineralization in the Finero Complex, Ivrea Zone, Southern Alps. Ore Geol. Rev. 2004, 24, 299-314. [CrossRef]

35. Hartmann, G.; Wedepohl, K.H. The composition of peridotite tectonites from the Ivrea Complex, northern Italy: Residues from melt extraction. Geochim. Cosmochim. Acta 1993, 57, 1761-1782. [CrossRef]

36. Siena, F.; Coltorti, M. The petrogenesis of a hydrated mafic ultramafic complex and the role of amphibole fractionation at Finero (Italian Western Alps). Neues Jahrb. fur Mineral. 1989, 6, 255-274.

37. Sills, J.D.; Ackermand, D.; Herd, R.K.; Windley, B.F. Bulk composition and mineral parageneses of sapphirine-bearing rocks along a gabbro-lherzolite contact at Finero, Ivrea Zone, N Italy. J. Metamorph. Geol. 1983, 1, 337-351. [CrossRef]

38. Christy, A.G. The stability of sapphirine + clinopyroxene: Implications for phase relations in the $\mathrm{CaO}-\mathrm{MgO}-\mathrm{Al}_{2} \mathrm{O}_{3}-\mathrm{SiO}_{2}$ system under deep-crustal and upper mantle conditions. Contrib. Mineral. Petrol. 1989, 102, 422-428. [CrossRef]

39. Henk, A.; Franz, L.; Teufel, S.; Oncken, O. Magmatic Underplating, Extension, and Crustal Reequilibration: Insights from A Cross-Section Through the Ivrea Zone and Strona-Ceneri Zone, Northern Italy. J. Geol. 1997, 105, 367-378. [CrossRef]

40. Wogelius, R.A.; Bishop, F.C. Subsolidus emplacement history of the Lanzo massif, northern Italy. Geology 1989, 17, 995-999. [CrossRef]

41. Pagé, P.; Barnes, S.-J. Using Trace Elements in Chromites to Constrain the Origin of Podiform Chromitites in the Thetford Mines Ophiolite, Québec, Canada. Econ. Geol. 2009, 104, 997-1018. [CrossRef]

42. González-Jiménez, J.M.; Griffin, W.L.; Proenza, J.A.; Gervilla, F.; O’Reilly, S.Y.; Akbulut, M.; Pearson, N.J.; Arai, S. Chromitites in ophiolites: How, where, when, why? Part II. The crystallization of chromitites. Lithos 2014, 189, 140-158. [CrossRef]

43. Kapsiotis, A.; Rassios, A.E.; Uysal, I.; Grieco, G.; Akmaz, R.M.; Saka, S.; Bussolesi, M. Compositional fingerprints of chromian spinel from the refractory chrome ores of Metalleion, Othris (Greece): Implications for metallogeny and deformation of chromitites within a "hot" oceanic fault zone. J. Geochem. Explor. 2018, 185, 14-32. [CrossRef] 